UDC 070.448

DOI: 10.24919/2519-058x.7.131214

Lidiva LAZURKO,

orcid 0000-0002-9748-9249

Ph D hab. (History), Assciate Professor, Ivan Franko Drohobych State Pedagogical University

(Drohobych, Ukraine, lazurkol@gmail.com)

\title{
LVIV CHRONICLE «PRZEGLĄD ARCHEOLOGICZNY» AND THE UKRAINIAN ISSUE
}

The article raises the issues of establishing and clarifying certain aspects of the first Lviv specifical$l y$ historical journal «Przeglad Archeologiczny» ("Archeological Review»). Established in 1876 with educational purposes, the journal focused on informing about the latest developments in the field of archeology, and at the same time, researches in various special historical fields and art history. On the pages of "Przeglad Archeologiczny" the first, to an extent amateur, explorations of Ukrainian sacral art and architecture as a distinct style that stirred sharp scientific debates and triggered the activation of the research in this area were published.

Key words: historiography, historical journal, «Przeglad Archeologiczny», Ukrainian sacral art.

Лідія ЛАЗУРКО, кандидат історичних наук, дочент кафедри історії України Дрогобииького державного педагогічного університету імені Івана Франка (Дрогобич, Україна) lazurkol@gmail.com

\section{ЛЬВІВСЬКИЙ ЧАСОПИС «PRZEGLĄD ARCНЕOLOGICZNY» ТА УКРАЇНСЬКА ТЕМАТИКА}

У статті піднімаються питання створення та з'ясування окремих аспектів діяльності першого львівського спеціально-історичного часопису "Przegląd Archeologicznу». Створений у 1876 р. з просвітницькою метою, часопис робив акиент на інформуванні про найновіші здобутки у галузі археології, не иураючись, водночас, досліджень у різноманітних спеціально-історичних иаринах та історії мистеитв. Саме на сторінках «Przegladu Archeologicznеgо» були опубліковані перші, дещо аматорські, розвідки про русинське сакральне мистецтво та архітектуру як окремий стиль, щчо сколихнуло гострі наукові дискусії та стало поштовхом до активізачіі досліджень у цьому напрямку.

Ключові слова: історіографія, історичний журнал, "Przeglad Archeologicznу», українське сакральне мистещтво.

The statement of the problem. In the XIX century archeology, in connection with an increase of interest to olden time subjects, started declaring its existence as a science. However, still for a long time, it remained within the domain of history of cultural and collected round itself admirers of the past of very different interests. The fashion for the past, which was partially maintained by archeology, did not bypass Ukrainian Galicia of that time. Here, in 1848, in the Zbruch river near the village of Horodnytsia, a wooden idol was casually found, a statue, which represented the pagan god Sviatovyd, that had thitherto been unknown. 
This find turned out an extremely strong stimulus which stipulated the appearance of a variety of scientific works of different character and marked the beginning of the search and studying of archeological finds in Galicia (Bulyk, 2005: 377). A wide coverage in press made the image of Sviatovyd for some time an original symbol of archaeological researches in East Galicia which turned out a powerful push for the further searches and realisation of organizational work. By the mid 1970s in Lviv a considerably large group of persons interested in archeology grew up, by which efforts on 31 December, 1875 the «Towarzystwo Archeologiczne Krajowe» («The Regional Archeological Society', further referred to as «RAS») with its own scientifical-informational tribune, that is a specialised historical journal «Archeological Review» («Przegląd Archeologiczny», further referred to as «AR») (CSHAU Central State Historical Archive of Ukraine - in Lviv, File 146, Opus 25, Case 48, Page 21).

The analysis of researches. The studying of the organizational-scientific activity of this organ's editorial board has not hitherto been a subject of separate researches. From the viewpoint of the context of Lviv press history, Ye. Yarovetskyi (Jarowiecki, 2008: 122) was the first to have referred to «AR» as a press organ, although, without specifying of the structure of that edition, which had been initially known as the aforementioned «RAS» (CSHAU in Lviv. F. 192. Op. 1. C. 6. Pp. 17-22), and later as «Towarzystwo Archeologiczne and c. k. Konserwatorium Pomników» («Archeological Society and the C[entral] C[omission] on the Conservation of Monuments»). Some more attention to «AR» as a special-historical journal was given by A. Tochek in his research devoted to Lviv scientific historical editions of the end of the XIX - beginning of the XX century. He presented an original historical reference of the journal's activity, having in brief concentrated on the illumination of features of its form and content (Toczek, 2005: 190-191). In the context of the formation of archeology as a sciences in Lviv H. Bulyk raised the issue of «AR», concentrating on questions of partiality of the «RAS» management in carrying out of the edition (Bulyk, 2008: 209-237). Also, $\mathrm{R}$. Masyk investigated the question of functioning of the journal in the context of history of the Archaeological society's activity. In particular, he accentuated on the demonstration of evolution of thematic interests of contributors to the edition, which he saw as due to the subordination of Lviv organisation of archeologists in 1882 to zealous tsarist service and corresponding changes in its tasks (Masyk, 2008: 157-170).

At various times the history of the regional archeology in view with the question of activity of one oldest Polish archaeological societies in Galician land and its publishing body was studied by B. Janusz, Y. Kostrzewski, A. Nadolski, A. Abramowicz, A. Feloniuk, I. Chornovol (Janusz, 1919: 20-22; Kostrzewsk i, 1949: 20; Nadolsk i, 1966: 170; Abramowicz, 1967: 153-154; Feloniuk, 2003: 16; Chornovol, 2005: 212-230). Nevertheless all these operating time had fragmentary character and do not give complete representation about «PA».

The article's purpose. This article treats of the questions of creation and initial activity of a special-historical journal «AR» as a platforms for discussion of questions of Ukrainian sacral art. In particular, the historiographic analysis of the content of the journal's publications concerning Ukrainian matters is carried out, the evolution of the edition's structure is investigated, and its editorial board's activity is clarified. Besides, among other adjacent questions, one of the most interesting one is that which concerns the functioning of journal «AR» at the background of that time historical science in general and within the context of formation of a Lviv historiographic branch in particular. After all, as the views of contemporary researchers prove, in questions of development of archaeological studies Lviv went abreast with the spirit and style of the epoch, as other big cities of Europe (Sytnyk, 2012: 14). 
The presentation of the basic ideas. The appearance of an archaeological society in East Galicia by the end of 1875 seems to be but a natural result of the increase of interest to prehistory, in which the contemporaty European nations sought their ethnic roots. As a matter of fact, the situation on the territory under consideration had its specificity connected with the stratification of interests of the two peoples, Poles and Ukrainians, equally persisten in pretending to these lands (Sytnyk, 2012: 14). However, in the time of which the given article is about, it was yet the search for old artifacts for the sake of preservation and knowledge, and not opposition, that was the basic research directive.

S. Krzyrzanivskyi (1841 - 1881), Krakow historian, archeologist, and heraldry expert, renowned admirer of fine art and old artifacts, became the ideological inspirer and creator of Lviv organisation of archeologists (The Chronicle of Regional Archeological Society / Kronika Towarzystwa archeologicznego krajowego, 1876: 29). Ye. Yanota, Professor of Lviv university, and K. Vidman became respectively the vice-president and the secretary of the Society, whereas J. Kolachkovsky became the deputy secretary.

The territorial specificity of the Society turned out to result in the fact, that - as N. Bulyk underlines - its structure by membership and language was Polish, but - as it existed within the environment of Lviv and East Galicia, it concentrated round itself Ukrainian researchers (Bulyk, 2008: 210). Thus, in the first list of the Society members one comes across the surname I. Sharanevych (CSHAU in Lviv. F. 192. Op. 1. Case 1. P. 4, 9-16). Later on A. Petrushevych joined in the active work in the Society and chronicle. To such - obviously intended «super-national» orientation of the organisation S. Krzyrzanivskyi's following words can readily testify: «... In our Society it is necessary to call scientists of all nationalities and tribes, and first of all - the cognate with us slavic tribes-brethren, to the common work on prehistoric archeology!» (Krzyrzanivskyi, 1876: 5). It should be notified, that this appeal was displayed also in the organisation's symbolics, which by common election was represented by the Zbruch river idol. A roundish sign was framed by the full name of Towarzystwo Archeologiczne Krajowe (Regional Archeological Society), and in its middle the figure of a pagan deity of Sviatovyd was surrounded by the inscriptions of his name in the Polish and Ukrainian languages and the runic signs. This symbol decorated the titles of all journal «AR's» issues.

The purpose of the newly created Society was formulated in $\S 2$ of its Statute as follows: «the protection of ancient finds, which is carried out by means of gathering, description (or photographing), and studying of various movable and immovable monuments concerning the past of Galicia and the Grand Princedom of Krakow» (CSHAU in Lviv. F. 192. Op. 1. Case 6. P. 17-22). Besides, the Society had to undertake the popularization of archeology by organizing of public discussions of its questions and publishing, - according to $\S 45$ of its Statute, - of journal «Archeological Review» (CSHAU in Lviv. F. 192. Op. 1. Case 6. P. 17-22). The image of the aforementioned idol from the Zbruch river became a symbol of the newly formed organisation. The symbol's sketch had been discussed over and accepted at the organising committee session on 12 January, 1876, and in due later time it was confirmed at the General meeting ((The Chronicle of Regional Archeological Society / Kronika Towarzystwa archeologicznego krajowego, 1876: 30).

The special-historical journal «AR» was published from 1876 to 1890 with different periodicity and, even, long pauses. Actually, at present its precise number of edited issues is not known. In Lviv 8 separate writing-books have survived: three writing-books of the annual edition printed in 1876 , the fourth that was published in 1877 , and also three writing-books 
of $1882-1883$ and one of 1888 which in 1890 was reedited. A more captious study of the content of this journal's issues allowed the researchers to assert that the editions of $1876-$ 1877,1882 - 1883 and 1888 differed by their content filling.

The previous plan of the edition implied a quarterly edition of issues, but already the first yearly edition had a serious pause connected with the technical moment - the work on its edition in the summer simply stood still because of its creators participation in archeological excavations. Already after the publication of the first issue the editorial board made a statement about the impossibility of regular editing.

The «AR's» first editor-in-chief was Antoniy Schneider, Lviv amateur historian, specialist in the local lore, archeologist, ethnographer, member of the administrative board of the Society, and its librarian. The structure of the first issue of the journal met the typical requiremqnts imposed on the scientifical-historical editions of that time. The first issue of the journal, one hundred pages thick, was divided into four headings: articles, review of the scientific literature in archeology (compiled by J. Kolachkovsky, historian of art, vice-president of the Society who worked as an engineer-railwayman), various scientific information (miscellanea), and the chronicle of the Society's activity (conducted by K. Vidman, one of the founders of Lviv organisation of archeologists and. also, its secretary).

Along with archeology, which dominated on the pages of the journal, theme on journal pages, the other subjects also found place here, like genealogy reserches, cause and effect publications, particularly, in the field of diplomatics and study of art reviews. To tell the truth, these latter appeared in the the second period of the journal's existence when V. Dzieduszycki became the head of the Society. It was with his name that the appearance on the pages of «AR» of sensational and ambiguously apprehended in scientific circles reearches on Ukrainian art was connected (Rudenko, 2004: 165-172).

V. Dzieduszycki's article about the St Bartholomew Roman-Catholic cathedral and St George's church in Drohobych, which - according to the author - was one of the small towns of the Red Rus' most interesting for the archeologist, became the first publication in 1883 issue. V. Dzieduszycki, enough prophetically as by then, wrote that «Drohobych, that had became known in the beginning of the 1880 s thanks to the neighbourhood to Boryslav, a town rich in oil, would shortly becomes one of the most outstanding towns in the region. But it would never becomes a typical modern faceless industrial town without the past and memoirs which are so many around the world» (Dzieduszycki, 1883: 6-15). In his research Dzieduszycki draw attention to the most ancient architectural complex of Drohobych, namely the cathedral and its defensive tower near it. The time of the construction of the latter author connected with the rule of Volodymyr Osmomysl in Peremyshl Principality. At the same time, he thought that the cathedlal, whose history was very closely intertwined with that of the city, had been constructed later on the place of an old, still pagan, sacred site. It is interesting, that Dzieduszycki's sketch in the journal was illustrated with the samples of drawings of Drohobych cathedral, its detailed plan, and pictures of its interior and reliefs.

As to the wooden St George's Church, Dzieduszycki concentrated on discussing of different hypotheses about its establishment. He did not consider the version, then much spread about, about queen Bona as its probable founder, and was inclined to support the opinion about someone from Jagiello kin still linked to the Ruthenian confession who could be the founder of it. For a plausible version he accepted also the legend that the church was exchanged for salt by the local merchants in the Right bank Ukraine and transported to Droho- 
bych. The author also gave the detailed description of this historical-religious monument, in which architecture and design east motives can be traced.

Dzieduszycki's next research was on the Rus' sacral art by which a bright sample Bohorodchany iconostasis - was sensationally found in 1880, the find not less resonant than the statue of Sviatovyd. According to the researcher, this relic as a whole, was not an isolated separate phenomenon as that time art critics wished to represent, but was a sample and display of an original work of art in the Ruthenian style which had no analogues throughout the Rus' space (Dzieduszycki, 1888: 91-130). In particular, V. Dzieduszycki in this research defended the idea of original Ruthenian art. About it he wrote: «It is not known, whether the Ruthenians had been the creators of the best images here produced, but the name «Ruthenian art» is not too brave at all. In the old Ruthenian voivodeships of Rzeczpospolita an art so original arouse that can have its own name as it is a separate Old Rus' school» (Dzieduszycki, 1888: 91-92). The researcher considered that the representatives of this art adhered to the Eastern Church canons, somewhat changed under the influence of the Western Church. However, the way in which the old masters represented traditional scenes was new: the biblical scenes were interpreted more freely, the represented figures were not static and often arose at a landscape background, and their clothes reflected the epoch of their creator.

According to Dzieduszycki's opinion, the works in which the Byzantian tradition was penetrated by the spirit of the West, appeared during the times of the Vasas, when the Old Rus' art had reached its period of blossoming. However, that blossoming lasted not long and shortly the Rus' art dissolved in the Italian baroque.

The aforementioned Bohorodchany iconostasis was the property of the monastery of the Maniava Hermitage in Pokutia. After its closing during the times of emperor Joseph, some Austrian official sold the iconostasis in Bohorodchany, in a modest wooden church, which was so close that some icons had to be cut off from the complex in order to install it. Among the other losses were some icons, drawn again by the unknown artists, and the compositions and elements damaged in the course of time. Dzieduszycki assumed that the painted images of the iconostasis derived from the XVI century, and the wooden inlaid elements came from the XVIII century. From the point of view of architectonics this iconostasis had something in common with the iconostasis of St Nicolas' Church in Buchach. As well as there, all the figures depicted in this iconostasis prayed in an eastern manners, but the Virgin and some angels had the hands folded up in a western manners. In fact, in this fragment the researcher saw the Bohorodvhany master an average intermediary between the West and the East.

In the same issue of the journal a detailed report on an archaeological exhibition in Lviv was published in 1885, which accompanied such a special event as the first congress of Polish archeologists (A Report on the archeological exhibition / Sprawozdanie o wystawie archeologicznej, 1888: 207-218). The author of the report accented on the value of scientific congresses on the whole, illustrating the importance of professional meetings of those interested in archeology, and gave the statistical data containing the information about the German societiy of anthropologists and archeologists in 1884 organized already its fifteenth meeting, and that archeologists of Russia gathered already in the sixth time. At the same time, for Polish researchers that was only the first professional meeting.

The question of the purposes and problems of the particular Lviv congress was brought up. They were formulated in the meeting's program and concerned the actual problem of the region of research, namely, - the absence of arrangements between representatives of different nations living in one territory, necessity of preservation of historical and archaeological 
monuments of each culture and of civilisation on the whole. The organizers of the congress considered that the proper attitude to the artefacts of the past, in particular, that had art value, could become extinct lest the level of national interest in and admiration of scientific researches would not be raised.

For the purpose of realisation of that discussion's declaration, the working languages of the meetings should be both Polish and Ukrainian, and the exhibition of monuments and excursions to Bohorodchany for the acquaintance with the famous iconostasis should be carried out by common efforts. B. Dzieduszycki himself showed an example by delivering a speech at the opening of the congress in the Polish and Ukrainian languages, and in a report on church painting in Rus' he characterised it from the point of view of architecture, painting, and carving.

To the most ancient Rus' painting monument the author enlisted frescos in the chapels of Vavel created during times of Kazimir Jagellonchyk. In them the Byzantian tradition was slightly mixed with the motives of West-European Renaissance. And the bloom of the Rus' painting proper, according to B. Dzieduszycki, took place during the time of Sigizmund III. To the most outstanding monuments of those times he enlisted Bohorodchany and Lviv (of St. Prakseda's Churche) iconostases. And already after Cossack wars on Ruthenian lands it was baroque style that dominated there, which best was revealed in Buchach and Krasna Pushcha iconostases with their outstanding unbelievable plastic sculptures from wood.

It should be noticed, that not all shared that admiration with which Dzieduszycki represented Ruthenian painting. But the question, raised by him in his researches concerning the novelty and certain sensational nature for those who had never paid attention to the Ukrainian art and had not even suspected of its existence, caused interest.

Somewhat earlier, in 1880, at the first J. Długocz congress of Polish historians in Krakow, M. Sokolovsky, for the purpose of finding out of mobile demarcation lines of eastern and western civilisation, raised a question of Ruthenian art. M. Sokolovsky touched the questions which fell outside of the limits of a highly specialised research and were of debatable character, as the author, contrarily to widespread representations, recognised the possibility of existence of the Ruthenian school of painting and concentrated researchers' attention on the necessity of studying of the Polish influences in the process of its formation. This problem was fed also by other researchers of Galician olden time monuments, both of Polish and Ukrainian sides. And the exhibition of old artifacts became a culmination of these discussions, having sensibly divided the thoughts of disputants.

From the tribune of the first Polish professional historical journal «Kwartalnik Historyczny» («Historical Quartarly»), created in 1887 in Lviv, a sharp enough criticism sounded. Already in the first issue the reader came across a rather long article devoted to this theme. The exhibition of old artifacts, wrote the observer, which had been organised in Lviv together with the congress of archeologists, had gained neither scientific, nor political achievements. Demonstratively enough called Polish-Ukrainian, it should have been a uniform argument or a compliment in honour of a separate Ruthenian civilisation of the land, an attempt of originality on the area of archeology and art ( $\Sigma$. Wystawa Archeologiczna / An Archeological Show, 1887: 24). The results of the exhibition were so inutile that if it were not for the introductory article by M. Sokolovsky on Ruthenian painting, there would have been no objects for criticism altogether. On the contrary, the small M. Sokolovsky's preface was admitted for a respectable one, written with method, taste, and erudition. However, according to the critic, what M. Sokolovsky accepted for a display of the separate Ruthenian art and its school, 
was only a testimony to inter-penetration and and interference of eastern and western arts (ibidem, 1887: 25).

In the same issue of the journal of 1887 a large polemicarticle by, W. Lozynsky (Łoziński) was published, concerning the aforementioned Dzieduszycki's work in which the question of an iconostasis from a Basilian monastery in the Maniava Hermitage was considered, which after its liquidation had been transferred to Bohorodchany church and in the end of the XIX century became «the most recent document» in the matter of Ukrainian painting (Sygma (Łoziński W.), 1887: 150).

The basic dispute in that article was pivoting round the question of existence of the Ukrainian school of painting which, according to V. Dzieduszycki, had developed under the influence of the free western civilisation, under the open sky of the European art (Dzieduszycki, 1888: 91-130). In his turn, V. Lozynsky on the basis of own stylistic, compositional and coloristic analysis of the iconostasis' elements and the painting technique assumed, that this monument of sacral art could not be the product of a separate Ukrainian school and called into question the very existence of the latter (Sygma (Łoziński W.), 1887: 149-209).

The conclusions. In the mid 1870s in Lviv at the initiative of S. Krzyżanowski and with an active support of admirers of old artefacts, the first in East Galicia «Towarzystwo Archeologiczne Krajowe» («Regional Archeological Society») was organized, which official speaker was journal «Przegląd Archeologiczny» («Archeological Review»), one of the first special-historical editions of Lviv. From 1876 to 1890 the journal was published with various periodicity caused by many objective reasons, mainly, by the problems of financial character and of content filling. The editors of the journal, which was created with the educational purpose, placed emphasis on informing about the most recent achievements in the field of archeology, at the same time, avoiding no researches in various special-historical fields and history of arts. Trying to stick to thebases of scientific tolerance, the Society's managers and contributors to the journal suggested publications of researches of cultural inheritance without accounting dfor the national identity of the investigated artefacts. As a result, in «AR» the first, though somewhat amateur in character, researches about the Ukrainian sacral art and architecture as a separate style were published, which stirred up sharp scientific discussions and became a push to activation of researches in this direction.

\section{BIBLIOGRAPHY}

ЦДІА м. Львів - Центральний державний історичний архів України у Львові.

Булик, 2008 - Булик Н. Археологічні осередки Львова (1875 - 1914): Наукові пошуки та польові здобутки // Археологічні дослідження Львівського університету. Вип. 11. Львів, 2008. C. 209-237.

Булик, 2008 - Булик Н. До питання про формування археологічної науки в Галичині у XIX столітті // Матеріали і дослідження з археології Прикарпаття і Волині. Вип. 9. Львів, 2005. C. 372-385.

Масик, 2008 - Масик Р. Крайове археологічне товариство у Львові (1875 - 1890) // Наукові зошити історичного факультету Львівського національного університету імені Івана Франка. Вип. 9-10. Львів, 2008. С. 157-170.

Руденко, 2004 - Руденко О. Естетичні погляди на сакральне мистецтво В. Дідушицького // Вісник Львівського університету. Філософські науки. Вип. 6. Львів, 2004. С. 165-172.

Ситник, 2012 - Ситник О. Археологічна наука у Львові (перша половина XX ст.). Львів Жешів, 2012. 365 с.

Фелонюк, 2003 - Фелонюк А. Крайове археологічне товариство у Львові // Літопис. № 10. Львів, 2003. С. 16-17. 
Чорновол, 2005 - Чорновол I. Володимир Антонович, граф Войцех Дідушицький і археологічний з'їзд у Львові 1885 р. // Wielokulturowe środowisko historyczne Lwowa w XIX i XX w., t. III. - Rzeszów, 2005. - S. 212-230.

Abramowicz, 1967 - Abramowicz A. Wiek archeologii. Problemy polskiej archeologii dziewiętnastowiecznej. Warszawa, 1967. $188 \mathrm{~s}$.

Dzieduszycki, 1883 - Dzieduszycki W. Fara łacińska i cerkiew św. Jura w Drohobyczu // Przegląd Archeologiczny. 1883. R. II. Z. 1. S. 6-15.

Dzieduszycki, 1888 - Dzieduszycki W. Ikonostas Bohorodczański // Przegląd Archeologiczny. 1888. R. II. Z. IV. S. 91-130.

Janusz, 1919 - Janusz B. Kultura przedhistoryczna Podola galicyjskiego. Lwow, 1919. 172 s.

Jarowiecki, 2008 - Jarowiecki J. Dzieje prasy polskiej we Lwowie do 1945 r. Kraków - Wrocław, 2008. $502 \mathrm{~s}$

Kostrzewski, 1949 - Kostrzewski J. Dzieje polskich badań prehistorycznych. Poznań, 1949. 219 s.

Kronika Towarzystwa Archeologicznego, 1876 - Kronika Towarzystwa Archeologicznego Krajowego we Lwowie // Przegląd Archeologiczny. 1876. R. I. Z. 1. S. 29-30.

Krzyżanowski, 1876 - Krzyżanowski S. Mowa miana dnia 20 lutego 1876 r. na pierwszym posiedzeniu wydziału // Przegląd Archeologiczny. 1876. R. I. Z. 1. S. 5.

Nadolski, 1966 - Nadolski A. Dzieje archeologii polskiej w XIX i XX w. // Studia i materiały z dziejow nauki polskiej, 1966. Seria A. Z. 9. S. 161-176.

Sprawozdanie o wystawie, 1888 - Sprawozdanie o wystawie archeologicznej we Lwowie w roku 1885 // Przegląd Archeologiczny. 1888. R. II. Z. IV. S. 207-218.

Sygma (Łoziński W.), 1887 - Sygma (Łoziński W.) Malarstwo Cerkiewne na Rusi // Kwartalnik Historyczny. 1887. R. I. Z. 1 S. 149-209.

Toczek, 2005 - Toczek A. Czasopiśmiennictwo historyczne we Lwowie // Wielokulturowe środowisko historyczne Lwowa w XIX i XX w., t. III., red. J. Maternicki, L. Zaszkilnjak. Rzeszów, 2005. S. $175-198$.

$\Sigma$. Wystawa Archeologiczna, 1887 - $\Sigma$. Wystawa Archeologiczna Polsko-Ruska we Lwowie. Tekst objaśnijący napisał Ludwik Wierzbicki. O malarstwie Maryan Sokołowski (Выстава археологичная польско-руская. Львовъ 1885) // Kwartalnik Historyczny. 1887. R. I. Z. I. S. 24-31.

\section{REFERENCES}

Tsentralnyi derzhavnyi istorychnyi arkhiv Ukrainy u Lvovi [Central state historical archive of Ukraine in Lviv. Galician vicegerency].

Bulyk, 2008 - Bulyk N. Arkheolohichni oseredky Lvova (1875 - 1914): Naukovi poshuky ta polovi zdobutky [Regional archeological society in Lviv (1875 - 1914)] // Arkheolohichni doslidzhennia Lvivskoho universytetu. Vyp. 11. Lviv, 2008. Pp. 209-237. [in Ukrainian]

Bulyk, 2008 - Bulyk N. Do pytannia pro formuvannia arkheolohichnoi nauky v Halychyni u XIX stolitti [On the formation of archeological science in Galicia in the XIX century] // Materialy i doslidzhennia z arkheolohii Prykarpattia i Volyni. Vyp. 9. Lviv, 2005. Pp. 372-385. [in Ukrainian]

Masyk, 2008 - Masyk R. Kraiove arkheolohichne tovarystvo u Lvovi (1875 - 1890) [Regional Archaeological Society in Lviv (1875 - 1890)] // Naukovi zoshyty istorychnoho fakultetu Lvivskoho natsionalnoho universytetu imeni Ivana Franka. Vyp. 9-10. Lviv, 2008. Pp. 157-170. [in Ukrainian]

Rudenko, 2004 - Rudenko O. Estetychni pohliady na sakralne mystetstvo V.Didushytskoho [The aesthetic views of sacred art of V. Didushytski] // Visnyk Lvivskoho universytetu. Filosofski nauky. Vyp. 6. Lviv, 2004. Pp. 165-172. [in Ukrainian]

Sytnyk, 2012 - Sytnyk O. Arkheolohichna nauka u Lvovi (persha polovyna XX st.). [Archaeological science in Lviv (first half of XX century)] Lviv - Rzheshiv, 2012. 365 p. [in Ukrainian]

Feloniuk, 2003 - Feloniuk A. Kraiove arkheolohichne tovarystvo u Lvovi [Regional Archaeological Society in Lviv] // Litopys. № 10. Lviv, 2003. Pp. 16-17. [in Ukrainian]

Chornovol, 2005 - Chornovol I. Volodymyr Antonovych, hraf Voitsekh Didushytskyi i arkheolohichnyi zizd u Lvovi 1885 r. [Volodymyr Antonovych, duke Woizech Dzieduszycki and archeological congress in Lviv in 1885] // Wielokulturowe środowisko historyczne Lwowa w XIX i XX w., T. III. Rzeszów, 2005. Pp. 212-230. [in Ukrainian] 
Abramowicz, 1967 - Abramowicz A. Wiek archeologii. Problemy polskiej archeologii dziewiętnastowiecznej [Wiek archeologii. Problemy polskiej archeologii dziewiętnastowiecznej]. Warszawa, 1967. 188 p. [in Polish]

Dzieduszycki, 1883 - Dzieduszycki W. Fara łacińska i cerkiew św. Jura w Drohobyczu [The Latin church and the church of Saint. Jura in Drohobych] // Przegląd Archeologiczny. 1883. R. II. Z. 1. Pp. 6-15. [in Polish]

Dzieduszycki, 1888 - Dzieduszycki W. Ikonostas Bohorodczański [Bohorodchany iconostasis] // PA. 1888. R. II. Z. IV. Pp. 91-130. [in Polish]

Janusz, 1919 - Janusz B. Kultura przedhistoryczna Podola galicyjskiego [The prehistoric culture of Galician]. Lwow, 1919. 172 p. [in Polish]

Jarowiecki, 2008 - Jarowiecki J. Dzieje prasy polskiej we Lwowie do 1945 r. [The The achievements of Polish press in Lviv by 1945] Kraków - Wrocław, 2008. 502 p. [in Polish]

Kostrzewski, 1949 - Kostrzewski J. Dzieje polskich badań prehistorycznych [The achievements of Polish studies of prehistory]. Poznań, 1949. 219 p. [in Polish]

Kronika Towarzystwa Archeologicznego, 1876 - Kronika Towarzystwa Archeologicznego Krajowego we Lwowie [The Chronicle of Regional archeological society in Lviv] // Przegląd Archeologiczny. 1876. R. I. Z. 1. Pp. 29-30. [in Polish]

Krzyżanowski, 1876 - Krzyżanowski S. Mowa miana dnia 20 lutego 1876 r. na pierwszym posiedzeniu wydziału [The Speech delivered on the 20th of February 1876 at the first meeting of the society] // Przegląd Archeologiczny. 1876. R. I. Z. 1. P. 5. [in Polish]

Nadolski, 1966 - Nadolski A. Dzieje archeologii polskiej w XIX i XX w. [The achievements of Polish archeologyin the XIX and XX cc.] // Studia i materiały z dziejow nauki polskiej, 1966. Seria A. Z. 9. Pp. 161-176. [in Polish]

Sprawozdanie o wystawie, 1888 - Sprawozdanie o wystawie archeologicznej we Lwowie w roku 1885 [Report of an archeological exhibition in Lviv in 1885] // Przegląd Archeologiczny. 1888. R. II. Z. IV. Pp. 207-218. [in Polish]

Sygma (Łoziński W.), 1887 - Sygma (Łoziński W.) Malarstwo Cerkiewne na Rusi [Church painting in Rus'] // Kwartalnik Historyczny. 1887. R. I. Z. 1. Pp. 149-209. [in Polish]

Toczek, 2005 - Toczek A. Czasopiśmiennictwo historyczne we Lwowie [Historical chronicles in Lviv] // Wielokulturowe środowisko historyczne Lwowa w XIX i XX w., t. III., red. J. Maternicki, L. Zaszkilnjak. Rzeszów, 2005. Pp. 175-198. [in Polish]

$\Sigma$. Wystawa Archeologiczna, $1887-\Sigma$. Wystawa Archeologiczna Polsko-Ruska we Lwowie [Polish-Ukrainian exhibition in Lviv] // Kwartalnik Historyczny. 1887. R. I. Z. I. Pp. 24-31. [in Polish] Стаття надійшла до редакиії 10.04.2018 р. 